\title{
In Silico Characterization of Pectate Lyase Protein Sequences from Different Source Organisms
}

\author{
Amit Kumar Dubey, ${ }^{1}$ Sangeeta Yadav, ${ }^{1}$ Manish Kumar, ${ }^{1}$ Vinay Kumar Singh, ${ }^{2}$ \\ Bijaya Ketan Sarangi, ${ }^{3}$ and Dinesh Yadav $^{1}$ \\ ${ }^{1}$ Department of Biotechnology, D.D.U Gorakhpur University, Gorakhpur 273 009, India \\ ${ }^{2}$ School of Biotechnology, B.H.U, Varanasi 221 005, India \\ ${ }^{3}$ Environmental Biotechnology Division, National Environmental Engineering Research Institute, Nehru Marg, Nagpur, \\ Maharashtra 440 020, India \\ Correspondence should be addressed to Dinesh Yadav, dinesh_yad@rediffmail.com \\ Received 21 June 2010; Accepted 15 August 2010 \\ Academic Editor: Leszek Kleczkowski
}

Copyright (๑) 2010 Amit Kumar Dubey et al. This is an open access article distributed under the Creative Commons Attribution License, which permits unrestricted use, distribution, and reproduction in any medium, provided the original work is properly cited.

A total of 121 protein sequences of pectate lyases were subjected to homology search, multiple sequence alignment, phylogenetic tree construction, and motif analysis. The phylogenetic tree constructed revealed different clusters based on different source organisms representing bacterial, fungal, plant, and nematode pectate lyases. The multiple accessions of bacterial, fungal, nematode, and plant pectate lyase protein sequences were placed closely revealing a sequence level similarity. The multiple sequence alignment of these pectate lyase protein sequences from different source organisms showed conserved regions at different stretches with maximum homology from amino acid residues 439-467, 715-816, and 829-910 which could be used for designing degenerate primers or probes specific for pectate lyases. The motif analysis revealed a conserved Pec_Lyase_C domain uniformly observed in all pectate lyases irrespective of variable sources suggesting its possible role in structural and enzymatic functions.

\section{Introduction}

The enzymes hydrolyzing pectic substances ubiquitously present in the plant kingdom forming major components of middle lamella are referred as pectinases. The production, purification, biochemical characterization, and application of pectinases have been extensively reviewed [1-10]. The pectinases include polygalacturonases, pectic esterases, pectin lyases, and pectate lyases depending on their mode of action [1].

Pectate lyase (PL, EC 4.2.2.2) cleaves the $\alpha-1,4$ glycosidic bonds of polygalacturonic acid via a $\beta$-elimination reaction producing unsaturated $\Delta 4,5$ bond at the nonreducing end of the polysaccharide and generates 4,5-unsaturated oligogalacturonates. Pectate lyase is widely distributed in diverse families of microorganisms and plants. The important members of bacterial family include Erwinia carotovora, Bacillus polymyxa, Klebsiella, Yersinia, Cytophaga, Pseudomonas, and Xanthomonas while in fungi Aspergillus,
Fusarium, and Penicillium are the most predominant source $[9,11-14]$.

A number of pectate lyase genes have been cloned, sequenced, and expressed from different source organism, namely, bacteria [15-22], fungi [23-25], yeast [26], nematode [27] and plants [14, 28].

The three-dimensional structures of various extracellular pectate lyase have been reported [29-36]. The pectate lyases, in general, have a parallel $\beta$-helix domain formed by parallelstrands folded into a large right-handed helix and a major loop region.

Amino acid sequence homology-based classification of pectate lyases into distinct families suggesting the possible evolution from different lineages has been reported [20, 35, 37-44]. In silico analysis of pectin lyase protein sequences has been recently reported [45].

This paper reports in silico characterization of pectate lyase protein sequences from different source organisms for homology search, multiple sequence alignment, phylogenetic 
TABLE 1: List of pectate lyase protein sequences with respective accession number from different source organisms.

\begin{tabular}{|c|c|c|}
\hline Group & Total number & Accession number (Source organism name) \\
\hline Nematode & 06 & $\begin{array}{l}\text { AAQ09004.1[Meloidogyne incognita], AAL66022.1|AF455757 1[Meloidogyne javanica], } \\
\text { AAF80747.1[Globodera rostochiensis], BAE48375.1[Bursaphelenchus mucronatus], } \\
\text { BAE48371.1[Bursaphelenchus xylophilus], BAI44500.1[Aphelenchus avenae] }\end{array}$ \\
\hline Plant & 17 & $\begin{array}{l}\text { CAA47630.1[Nicotiana tabacum], NP 001150723.1[Zea mays], AAA33398.1[Lilium longiflorum], } \\
\text { CAA70735.1[Zinnia elegans], AAQ84042.1[Malus x domestica], BAE48664.1| Prunus mume], } \\
\text { AAY85180.1[Gossypium hirsutum], AAF63756.1|AF243475 1[Vitis vinifera], BAB59066.1[Salix gilgiana], } \\
\text { gi|1256509| emb|CAA63496.1[Musa acuminata], AAK66161.1[Fragaria x ananassa], BAF43573.1[Prunus } \\
\text { persica], ACF40835.1[Manilkara zapota], ABG66729.2[Carica papaya], AAM63307.1[ Arabidopsis thaliana], } \\
\text { ABR26682.1[Fragaria chiloensis], ABD47739.1[Eucalyptus globulus subsp. Globules }\end{array}$ \\
\hline Fungi & 10 & $\begin{array}{l}\text { AAA80568.1[Emericella nidulans], ABM60783.1[Penicillium citrinum], AAA75471.1[Glomerella cingulata], } \\
\text { AAC64368.1[Fusarium oxysporum f. sp. lycopersici], ACS78057.1[ Fusarium oxysporum f. cubense], } \\
\text { EEY55044.1[Phytophthora infestans T30-4], XP 749217.1[Aspergillus fumigatus Af293], } \\
\text { AAA80568.1[Emericella nidulans], ABM60783.1[Penicillium citrinum], EEY23761.1[Verticillium albo-atrum } \\
\text { VaMs.102] }\end{array}$ \\
\hline Bacteria & 87 & 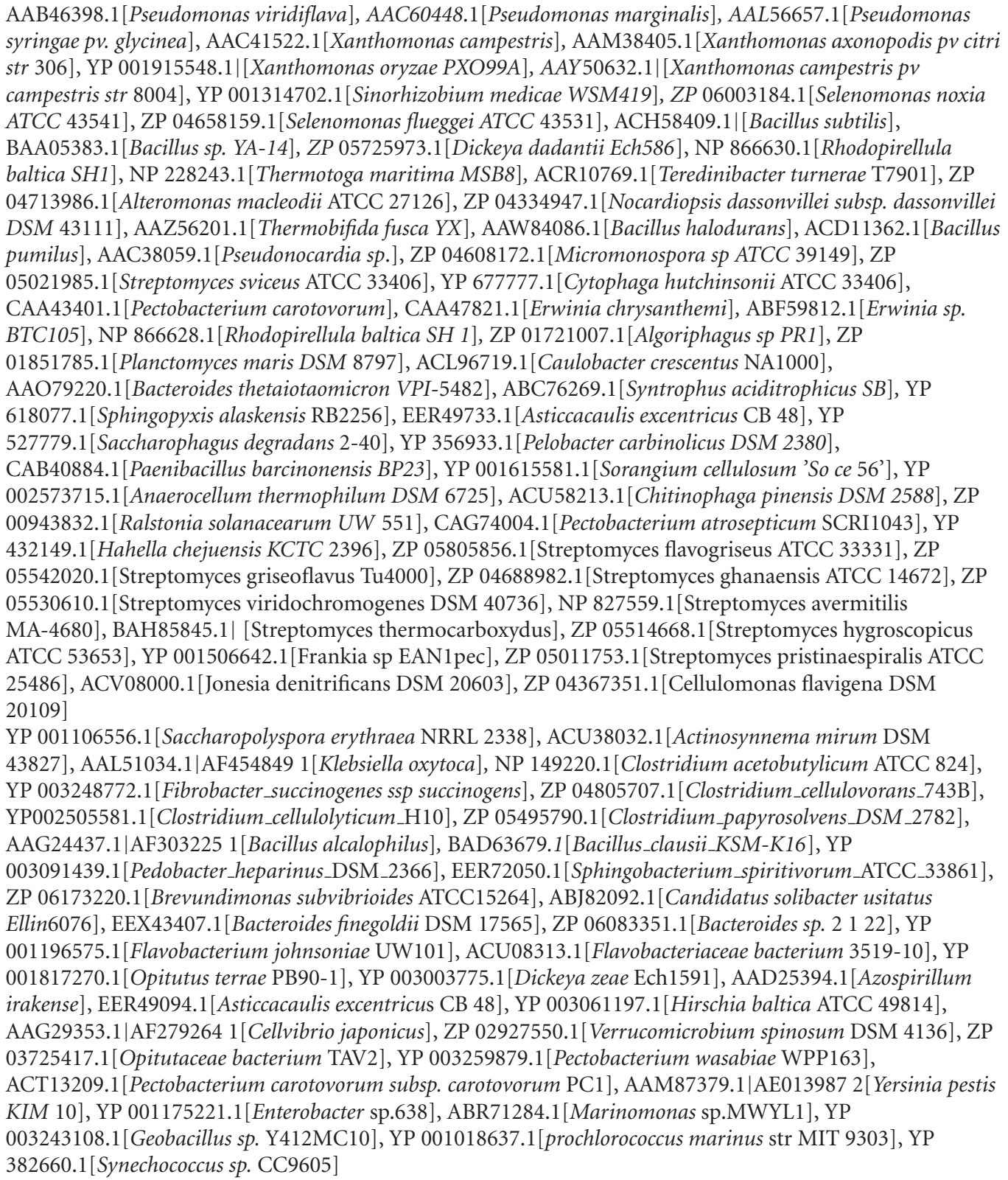 \\
\hline
\end{tabular}


TABLE 2: Distribution of motifs among 91 pectate lyase proteins sequences from different source organisms.

\begin{tabular}{|c|c|c|c|c|c|c|}
\hline S. no. & Accession no. & Motif 1 & Motif 2 & Motif 3 & Motif 4 & Motif 5 \\
\hline 1 & AAB46398 & + & & & + & \\
\hline 2 & CAB40884 & & & & & + \\
\hline 3 & CAA47630 & + & + & + & + & \\
\hline 4 & CAA70735 & + & + & + & + & \\
\hline 5 & CAA43401 & & & & + & \\
\hline 6 & CAA47821 & + & & & & \\
\hline 7 & NP866630 & + & + & & + & \\
\hline 8 & YP003003775 & & & & + & \\
\hline 9 & ZP05725973 & + & & & + & \\
\hline 10 & NP866628 & + & + & & + & + \\
\hline 11 & ZP05805856 & & & & & + \\
\hline 12 & YP002573715 & & & & & + \\
\hline 13 & YP001506642 & & & & & + \\
\hline 14 & NP001150723 & + & + & + & + & \\
\hline 15 & BAE48375 & & & & & + \\
\hline 16 & BAE48371 & & & & & + \\
\hline 17 & AAD25394 & + & & & & \\
\hline 18 & ACV08000 & & & & & + \\
\hline 19 & ACU58213 & & & & & ++ \\
\hline 20 & AAC60448 & + & + & & + & \\
\hline 21 & BAI44500 & & & & & + \\
\hline 22 & YP001314702 & + & & & + & \\
\hline 23 & AAQ09004 & & & & & + \\
\hline 24 & AAL66022.1|AF455757_1 & & & & & + \\
\hline 25 & AAF80747 & & & & & + \\
\hline 26 & AAC64368 & & & & & + \\
\hline 27 & AAA33398 & + & + & + & + & \\
\hline 28 & ACU38032 & & & & & + \\
\hline 29 & ACR10769 & + & + & + & & \\
\hline 30 & ACU08313 & & & & + & \\
\hline 31 & BAH85845 & & & & & + \\
\hline 32 & ACS78057 & & & & & + \\
\hline 33 & ZP04367351 & & & & & + \\
\hline 34 & AAW84086 & + & & + & & \\
\hline 35 & AAL56657 & + & + & + & + & \\
\hline 36 & AAK66161 & + & + & + & + & \\
\hline 37 & AAQ84042 & + & + & + & + & \\
\hline 38 & AAC41522 & + & & & + & \\
\hline 39 & AAA80568 & + & & & + & + \\
\hline 40 & ZP06003184 & + & & & + & \\
\hline 41 & ACH58409 & + & & + & + & \\
\hline 42 & AAF63756.1|AF243475_1 & + & + & + & + & \\
\hline 43 & ZP04713986 & + & & & & \\
\hline 44 & ZP04334947 & + & & + & & \\
\hline 45 & ABG66729 & + & + & + & + & \\
\hline 46 & ABR26682 & + & + & + & + & \\
\hline 47 & ACD11362 & + & & + & & \\
\hline 48 & XP749217 & + & & & + & \\
\hline 49 & BAA05383 & + & & & + & \\
\hline 50 & BAB59066 & + & + & + & + & \\
\hline 51 & ZP01851785 & + & + & & & + \\
\hline
\end{tabular}


Table 2: Continued.

\begin{tabular}{|c|c|c|c|c|c|c|}
\hline S. no. & Accession no. & Motif 1 & Motif 2 & Motif 3 & Motif 4 & Motif 5 \\
\hline 52 & ABM60783 & + & & & + & + \\
\hline 53 & BAF43573 & + & + & + & + & \\
\hline 54 & ABF59812 & + & & & & \\
\hline 55 & AAY85180 & + & + & + & + & \\
\hline 56 & EEY55044 & & & & & + \\
\hline 57 & EEY23761 & & & & + & + \\
\hline 58 & YP001615581 & & & & + & + \\
\hline 59 & ZP05542020 & & & & & + \\
\hline 60 & ZP05530610 & & & & & + \\
\hline 61 & ZP05514668 & & & & & + \\
\hline 62 & ZP05011753 & & & & & + \\
\hline 63 & ZP04688982 & & & & & + \\
\hline 64 & YP001106556 & & & & & + \\
\hline 65 & NP827559 & & & & & + \\
\hline 66 & YP432149 & & & & & + \\
\hline 67 & ABD47739 & + & & + & + & \\
\hline 68 & ZP00943832 & & & & & + \\
\hline 69 & AAM63307 & + & + & + & + & \\
\hline 70 & AAC38059 & + & + & & + & \\
\hline 71 & AAA75471 & + & & & + & \\
\hline 72 & ACL96719 & + & + & & & \\
\hline 73 & AAZ56201 & + & & + & & \\
\hline 74 & AAY50632 & + & & & + & + \\
\hline 75 & AAM38405 & + & & & + & \\
\hline 76 & YP618077 & + & + & & & \\
\hline 77 & ZP04608172 & + & & & + & \\
\hline 78 & ZP05021985 & + & & & + & \\
\hline 79 & ZP04658159 & + & & & + & \\
\hline 80 & YP001915548 & + & & & + & \\
\hline 81 & NP228243 & + & + & & + & \\
\hline 82 & YP356933 & & + & & & \\
\hline 83 & YP677777 & + & & & + & \\
\hline 84 & ACF40835 & + & + & + & + & \\
\hline 85 & CAA63496 & + & + & + & + & \\
\hline 86 & AAO79220 & + & + & + & & \\
\hline 87 & $\mathrm{ABC} 76269$ & + & + & & & \\
\hline 88 & ZP01721007 & + & + & & & \\
\hline 89 & BAE48664 & + & + & + & + & \\
\hline 90 & EER49733 & + & + & & & \\
\hline 91 & AAL51034.1|AF454849_1 & & & & + & \\
\hline 92 & YP527779.1| & & + & & & \\
\hline
\end{tabular}

TABLE 3: Different motifs commonly observed in pectate lyases protein sequences with best possible match amino acid sequences.

\begin{tabular}{lccc}
\hline $\begin{array}{l}\text { Motif } \\
\text { number }\end{array}$ & Width & Sequence & $\begin{array}{c}\text { Occurrence in pectate lyase } \\
\text { protein sequences }\end{array}$ \\
\hline 1 & 29 & IAFNHFGEGLVQRMPRCRHGYFHVVNNDY & 47 \\
2 & 50 & NPRPGTLRHAVIQDEPLWIVFKRDMVIQLKQELIMNSFKTIDGRGVNVHI & 16 \\
3 & 50 & CITIQFVTNIIIHGIHIHDCKPTGNAMVRSSPSHYGWRTMADGDGISIFG & 16 \\
4 & 50 & HNSLSNCHDGLIDAIHGSTAITISNNYMTHHDKVMLLGHSDSYTQDKNMQ & 39 \\
5 & 49 & SSSQTMTVDGGGARYAHDKVFQHNGPGTFVIKNFQVQDFGKLYRSCGNC & 27 \\
\hline
\end{tabular}




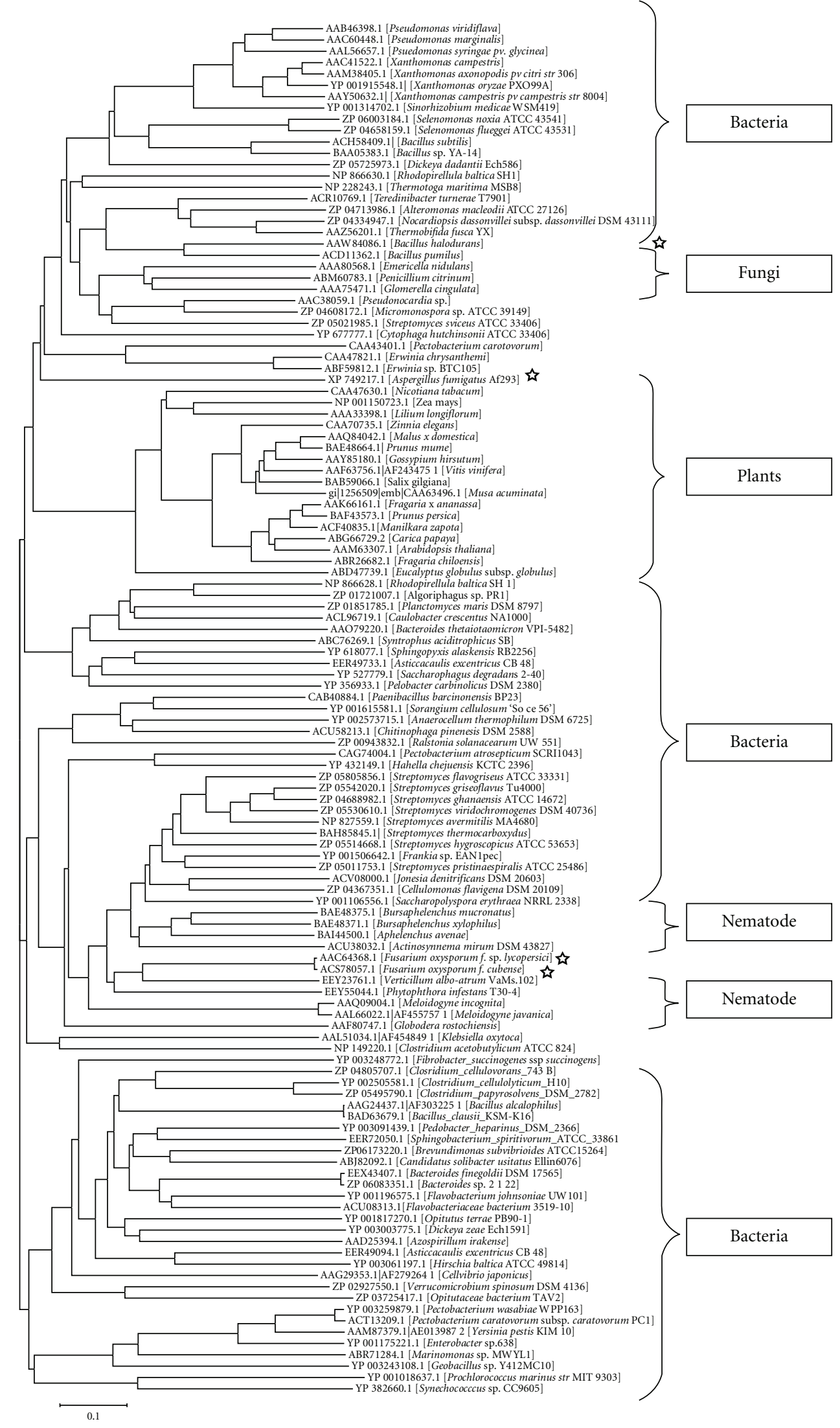

FIGURE 1: Phylogenetic tree of pectate lyase protein sequences from different source organism constructed by NJ method. 


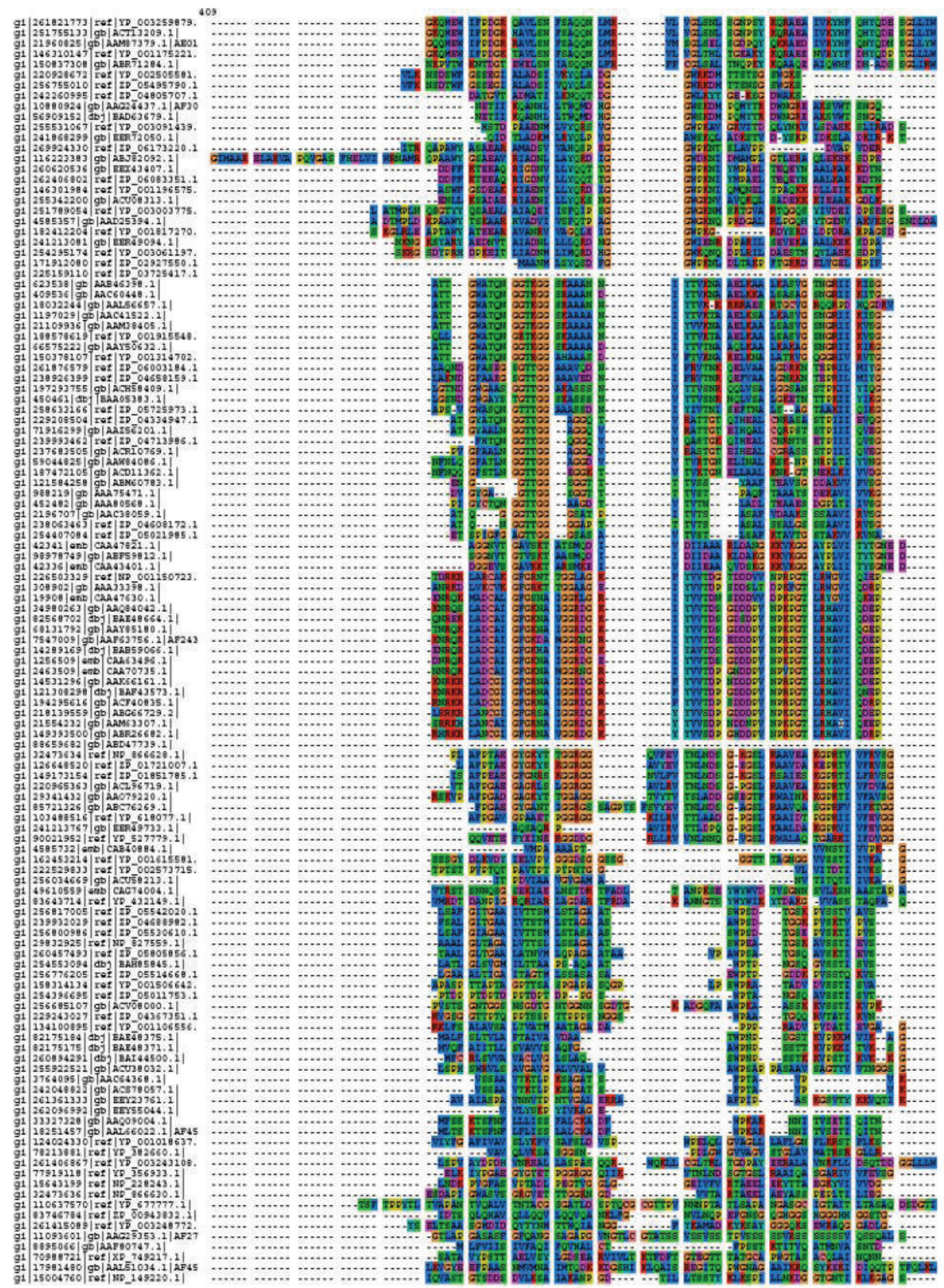




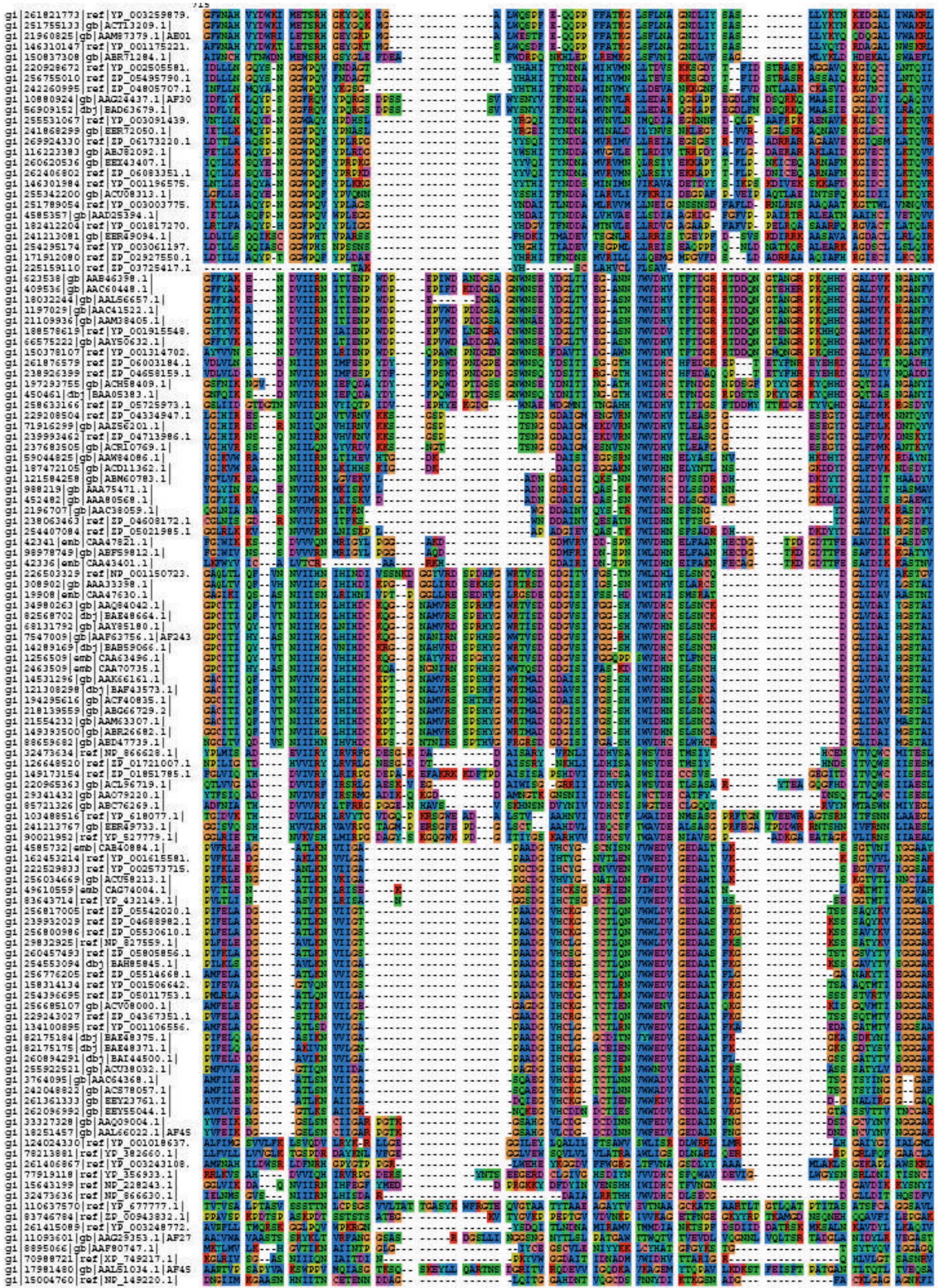




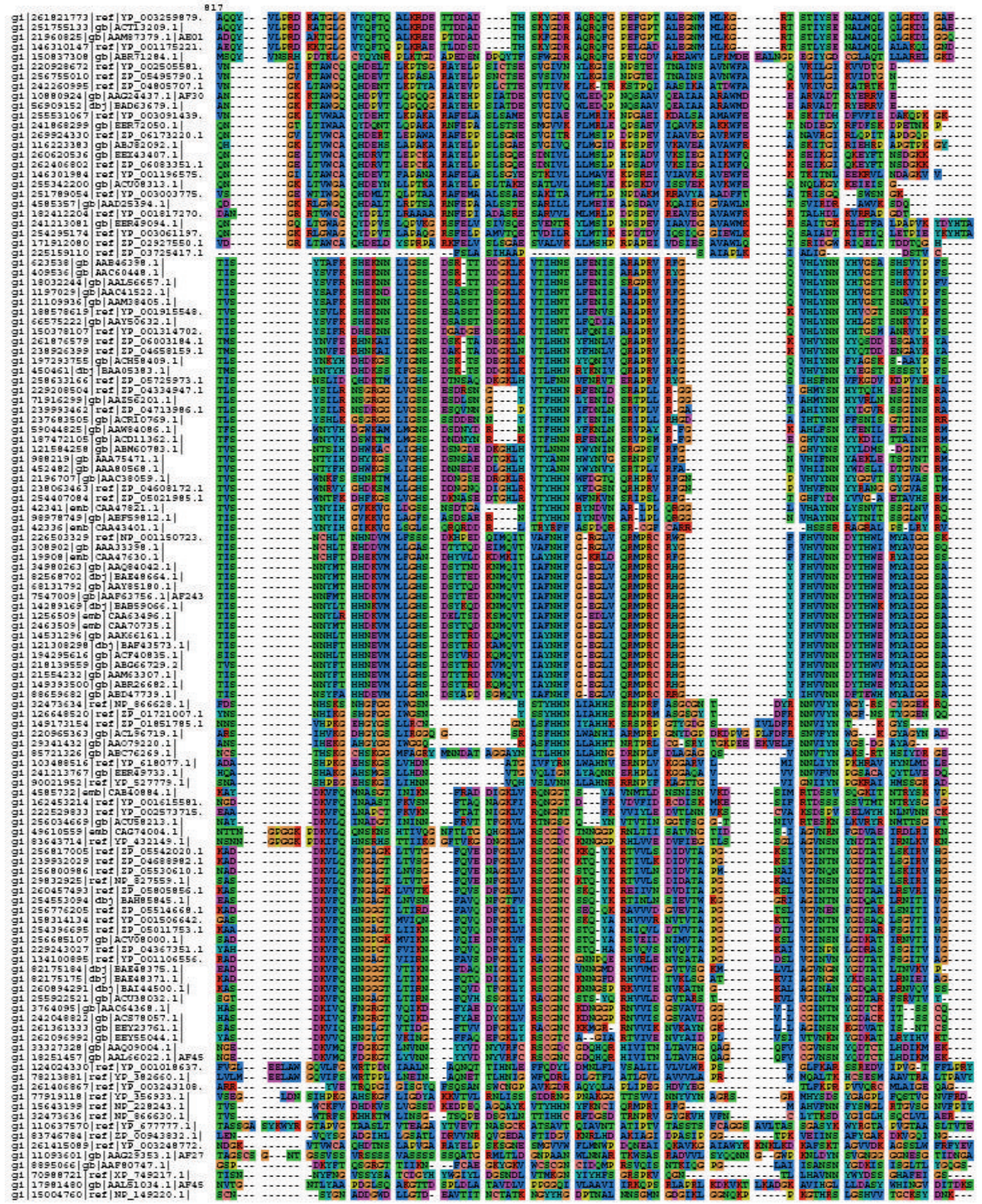

(c)

Figure 2: (a) Multiple sequence alignment of pectate lyase protein sequences showing maximum homology from amino acid residues 439467. (b) Multiple sequence alignment of pectate lyase protein sequences showing maximum homology from amino acid residues 715-816. (c) Multiple sequence alignment of pectate lyase protein sequences showing maximum homology from amino acid residues 829-910. 
tree construction, and motif analysis using various bioinformatics tools.

\section{Materials and Methods}

A total of 121 protein sequences of pectate lyases of different source organism available in GenBank were downloaded from NCBI (http://www.ncbi.nlm.nih.gov/). The accession numbers of pectate lyases protein sequences along with the source organism are listed in Table 1.

The program ClustalW [46] was used for multiple sequence alignment. Mega 4 was used for dendrogram construction by Neighbor-Joining (NJ) method [47]. For domain search, the Pfam site (http://www.sanger.ac.uk/software/pfam/search.html) was used. Domain analysis was done using MEME (http://meme.sdsc.edu/meme/meme $. h t m l)$ [48]. The conserved protein motifs deduced by MEME were characterized for biological function analysis using protein BLAST, and domains were studied with Interproscan providing the best possible match based on highest similarity score.

\section{Results and Discussion}

A total of 121 pectate lyases sequences from different source organisms subjected to phylogenetic tree construction revealed major clusters of bacterial, fungal, plant, and nematode pectate lyases. The pectate lyase from bacterial source was the predominant comprising of 87 accession numbers. The different accession of bacterial pectate lyase formed three major clusters as shown in Figure 1. The plant, fungal, and nematode pectate lyases formed separate clusters signifying the sequence-based similarity with reference to different source organisms. The multiple accessions of bacterial, fungal, plant, and nematode pectate lyases were placed closely in the clusters signifying the greater degree of sequence level similarity. Similar phylogenetic tree revealing clustering of pectin lyases protein sequences based on different source organism has been reported [45].

The multiple sequence alignment of these protein sequences revealed conserved regions at different stretches, namely, from 439-467, 715-816, and 829-918 amino acid residues (Figures 2(a), 2(b), and 2(c)). This region could be used for designing degenerate primers or probes for PCR-based amplification or hybridization-based detection of pectate lyase sequences from different source organisms.

A total of five motifs labelled as 1, 2, 3, 4, and 5 were observed in only 91 sequences when subjected to MEME. The distribution of these motifs among 92 pectate lyase accession number is shown in Table 2.

The motifs with width and best possible match amino acid sequences are shown in Table 3. All these motifs showed similarity with pec_lyase_C domain which is quite prevalent in pectin lyase sequences as reported earlier [45]. As the mechanism of pectin lyase and pectate lyase is quite similar, it is expected to show similar motifs. The motif 1 of 29 amino acid residues with sequence IAFNHFGEGLVQRMPRCRHGYFHVVNNDY and motif 4 of 50 amino acid residues with a sequence HNSLSNCHDGLIDAIHGSTAITISNNYMTHHDKVMLLGHSDSYTQDKNMQ were observed in 47 and 39 pectate lyase protein sequences (Table 3) signifying their possible role in the structural and catalytic attributes of pectate lyases.

Further when the motif best possible match amino acid sequence was subjected to BLAST to reveal its identity, it was observed that the motifs $1,2,3$, and 4 represents Pec_Lyase_C superfamily while motif 5 represents pectate lyase superfamily. The exact function of these motifs in influencing the catalytic activity of the pectate lyase needs to be investigated.

The in silico characterization of pectate lyases protein sequences from different source organisms has revealed sequence level similarity specific for different groups which could be utilized for designing strategy for cloning the putative genes based on PCR amplification using degenerate primers.

\section{Acknowledgments}

The authors wish to acknowledge Head, Department of Biotechnology, D.D.U Gorakhpur University, Gorakhpur for providing the infrastructural facilities. The facilities provided by DBT-funded SUB-DIC, Bioinformatics centre, School of Biotechnology, BHU, Varanasi are also thankfully acknowledged. The financial support by UGC, India in the form of UGC- Major Project (F. no.37-133/2009-SR) to D. Yadav and by DST, India in the form of Fast Track Young Scientist Fellowship (FT/LS-125/2008) to S. Yadav is duly acknowledged.

\section{References}

[1] I. Alkorta, C. Garbisu, M. J. Llama, and J. L. Serra, "Industrial applications of pectic enzymes: a review," Process Biochemistry, vol. 33, no. 1, pp. 21-28, 1998.

[2] G. S. N. Naidu and T. Panda, "Production of pectolytic enzymes-a review," Bioprocess Engineering, vol. 19, no. 5, pp. 355-361, 1998.

[3] C. Lang and H. Dörnenburg, "Perspectives in the biological function and the technological application of polygalacturonases," Applied Microbiology and Biotechnology, vol. 53, no. 4, pp. 366-375, 2000.

[4] D. R. Kashyap, P. K. Vohra, S. Chopra, and R. Tewari, "Applications of pectinases in the commercial sector: a review," Bioresource Technology, vol. 77, no. 3, pp. 215-227, 2001.

[5] G. Hoondal, R. Tiwari, R. Tewari, N. Dahiya, and Q. Beg, "Microbial alkaline pectinases and their industrial applications: a review," Applied Microbiology and Biotechnology, vol. 59, no. 4-5, pp. 409-418, 2002.

[6] S. N. Gummadi and T. Panda, "Purification and biochemical properties of microbial pectinases-a review," Process Biochemistry, vol. 38, no. 7, pp. 987-996, 2003.

[7] R. S. Jayani, S. Saxena, and R. Gupta, "Microbial pectinolytic enzymes: a review," Process Biochemistry, vol. 40, no. 9, pp. 2931-2944, 2005.

[8] S. N. Gummadi and D. S. Kumar, "Microbial pectic transeliminases," Biotechnology Letters, vol. 27, no. 7, pp. 451-458, 2005. 
[9] A. Payasi, R. Sanwal, and G. G. Sanwal, "Microbial pectate lyases: characterization and enzymological properties," World Journal of Microbiology and Biotechnology, vol. 25, no. 1, pp. 1-14, 2008.

[10] S. Yadav, P. K. Yadav, D. Yadav, and K. D. S. Yadav, "Pectin lyase: a review," Process Biochemistry, vol. 44, no. 1, pp. 1-10, 2009.

[11] M. C. Marín-Rodríguez, J. Orchard, and G. B. Seymour, "Pectate lyases, cell wall degradation and fruit softening," Journal of Experimental Botany, vol. 53, no. 377, pp. 21152119, 2002.

[12] M. C. Marín-Rodríguez, D. L. Smith, K. Manning, J. Orchard, and G. B. Seymour, "Pectate lyase gene expression and enzyme activity in ripening banana fruit," Plant Molecular Biology, vol. 51, no. 6, pp. 851-857, 2003.

[13] A. Payasi and G. G. Sanwal, "Pectate lyase activity during ripening of banana fruit," Phytochemistry, vol. 63, no. 3, pp. 243-248, 2003.

[14] A. Payasi, P. C. Misra, and G. G. Sanwal, "Purification and characterization of pectate lyase from banana (Musa acuminata) fruits," Phytochemistry, vol. 67, no. 9, pp. 861-869, 2006.

[15] M. Soriano, A. Blanco, P. Díaz, and F. I. J. Pastor, "An unusual pectate lyase from a Bacillus sp. with high activity on pectin: cloning and characterization," Microbiology, vol. 146, no. 1, pp. 89-95, 2002.

[16] K. Sawada, A. Ogawa, T. Ozawa et al., "Nucleotide and aminoacid sequences of a new-type pectate lyase from an alkaliphilic strain of Bacillus," European Journal of Biochemistry, vol. 267, no. 5, pp. 1510-1515, 2000.

[17] L. V. Truong, H. Tuyen, E. Helmke, L. T. Binh, and T. Schweder, "Cloning of two pectate lyase genes from the marine Antarctic bacterium Pseudoalteromonas haloplanktis strain ANT/505 and characterization of the enzymes," Extremophiles, vol. 5, no. 1, pp. 35-44, 2001.

[18] T. Matsumoto, D. Katsura, A. Kondo, and H. Fukuda, "Efficient secretory overexpression of Bacillus subtilis pectate lyase in Escherichia coli and single-step purification," Biochemical Engineering Journal, vol. 12, no. 3, pp. 175-179, 2002.

[19] L. D. Kluskens, G.-J. W. M. Van Alebeek, A. G. J. Voragen, W. M. De Vos, and J. van der Oost, "Molecular and biochemical characterization of the thermoactive family 1 pectate lyase from the hyperthermophilic bacterium Thermotoga maritima," Biochemical Journal, vol. 370, no. 2, pp. 651-659, 2003.

[20] M. Soriano, P. Diaz, and F. I. J. Pastor, "Pectate lyase C from Bacillus subtilis: a novel endo-cleaving enzyme with activity on highly methylated pectin," Microbiology, vol. 152, no. 3, pp. 617-625, 2006.

[21] S. Kaewnum, S. Prathuangwong, and T. J. Burr, "A pectate lyase homolog, xagP, in Xanthomonas axonopodis pv. glycines is associated with hypersensitive response induction on tobacco," Phytopathology, vol. 96, no. 11, pp. 1230-1236, 2006.

[22] Z. Xiao, H. Bergeron, S. Grosse et al., "Improvement of the thermostability and activity of a pectate lyase by single amino acid substitutions, using a strategy based on meltingtemperature-guided sequence alignment," Applied and Environmental Microbiology, vol. 74, no. 4, pp. 1183-1189, 2008.

[23] J. Shih, Y. Wei, and P. H. Goodwin, "A comparison of the pectate lyase genes, pel-1 and pel-2, of Colletotrichum gloeosporioides f.sp. malvae and the relationship between their expression in culture and during necrotrophic infection," Gene, vol. 243, no. 1-2, pp. 139-150, 2000.
[24] R. P. De Vries, J. Jansen, G. Aguilar et al., "Expression profiling of pectinolytic genes from Aspergillus niger," FEBS Letters, vol. 530, no. 1-3, pp. 41-47, 2002.

[25] Q. Zhao, S. Yuan, Y. Zhang et al., "Expression, purification and characterization of pectate lyase a from Aspergillus nidulans in Escherichia coli," World Journal of Microbiology and Biotechnology, vol. 23, no. 8, pp. 1057-1064, 2008.

[26] R. Margesin, V. Fauster, and P.-A. Fonteyne, "Characterization of cold-active pectate lyases from psychrophilic Mrakia frigida," Letters in Applied Microbiology, vol. 40, no. 6, pp. 453459, 2005.

[27] E. A. Doyle and K. N. Lambert, "Cloning and characterization of an esophageal-gland-specific pectate lyase from the root-knot nematode Meloidogyne javanica," Molecular PlantMicrobe Interactions, vol. 15, no. 6, pp. 549-556, 2002.

[28] N. Medina-Escobar, J. Cárdenas, E. Moyano, J. L. Caballero, and J. Muñoz-Blanco, "Cloning, molecular characterization and expression pattern of a strawberry ripening-specific cDNA with sequence homology to pectate lyase from higher plants," Plant Molecular Biology, vol. 34, no. 6, pp. 867-877, 1997.

[29] M. D. Yoder, N. T. Keen, and F. Jurnak, "New domain motif: the structure of pectate lyase C, a secreted plant virulence factor," Science, vol. 260, no. 5113, pp. 1503-1507, 1993.

[30] S. E. Lietzke, M. D. Yoder, N. T. Keen, and F. Jurnak, "The three-dimensional structure of pectate lyase E, a plant virulence factor from Erwinia chrysanthemi," Plant Physiology, vol. 106, no. 3, pp. 849-852, 1994.

[31] R. Pickersgill, J. Jenkins, G. Harris, W. Nasser, and J. RobertBaudouy, "The structure of Bacillus subtilis pectate lyase in complex with calcium," Nature Structural Biology, vol. 1, no. 10, pp. 717-723, 1994.

[32] O. Mayans, M. Scott, I. Connerton et al., "Two crystal structures of pectin lyase A from Aspergillus reveal a $\mathrm{pH}$ driven conformational change and striking divergence in the substrate-binding clefts of pectin and pectate lyases," Structure, vol. 5, no. 5, pp. 677-689, 1997.

[33] J. Vitali, B. Schick, H. C. M. Kester, J. Visser, and F. Jurnak, "The three-dimensional structure of Aspergillus niger pectin lyase b at 1.7-Å resolution,” Plant Physiology, vol. 116, no. 1, pp. 69-80, 1998.

[34] M. D. Yoder and F. Jurnak, "The refined three-dimensional structure of pectate lyase C from Erwinia chrysanthemi at $2.2 \AA$ resolution," Plant Physiology, vol. 107, no. 2, pp. 349-364, 1994.

[35] S. R. Herron, J. A. E. Benen, R. D. Scavetta, J. Visser, and F. Jurnak, "Structure and function of pectic enzymes: virulence factors of plant pathogens," Proceedings of the National Academy of Sciences of the United States of America, vol. 97, no. 16 , pp. 8762-8769, 2000.

[36] J. Jenkins, V. E. Shevchik, N. Hugouvieux-Cotte-Pattat, and R. W. Pickersgill, "The crystal structure of pectate lyase Pel9A from Erwinia chrysanthemi," Journal of Biological Chemistry, vol. 279, no. 10, pp. 9139-9145, 2004.

[37] L. Gonzalez-Candelas and P. E. Kolattukudy, "Isolation and analysis of a novel inducible pectate lyase gene from the phytopathogenic fungus Fusarium solani f. sp. pisi (Nectria haematococca, mating population VI)," Journal of Bacteriology, vol. 174, no. 20, pp. 6343-6349, 1992.

[38] M. A. Bekri, J. Desair, V. Keijers et al., "Azospirillum irakense produces a novel type of pectate lyase," Journal of Bacteriology, vol. 181 , no. 8, pp. 2440-2447, 1999. 
[39] V. E. Shevchik, J. Robert-Baudouy, and N. HugouvieuxCotte-Pattat, "Pectate lyase PelI of Erwinia chrysanthemi 3937 belongs to a new family," Journal of Bacteriology, vol. 179, no. 23, pp. 7321-7330, 1997.

[40] Y. Hatada, T. Kobayashi, and S. Ito, "Enzymatic properties of the highly thermophilic and alkaline pectate lyase Pel-4B from alkaliphilic Bacillus sp. strain P-4-N and the entire nucleotide and amino acid sequences," Extremophiles, vol. 5, no. 2, pp. 127-133, 2001.

[41] C. Zhai, J. Cao, and Y. Wang, "Cloning and expression of a pectate lyase gene from Bacillus alcalophillus NTT33," Enzyme and Microbial Technology, vol. 33, no. 2-3, pp. 173-178, 2003.

[42] S. J. Dehdashti, C. N. Doan, K. L. Chao, and M. D. Yoder, "Effect of mutations in the T1.5 loop of pectate lyase A from Erwinia chrysanthemi EC16," Acta Crystallographica, vol. 59, no. 7, pp. 1339-1342, 2003.

[43] S. Berensmeier, S. A. Singh, J. Meens, and K. Buchholz, "Cloning of the pelA gene from Bacillus licheniformis 14A and biochemical characterization of recombinant, thermostable, high-alkaline pectate lyase," Applied Microbiology and Biotechnology, vol. 64, no. 4, pp. 560-567, 2004.

[44] W. Guo, L. Gonzalez-Candelas, and P. E. Kolattukudy, "Cloning of a novel constitutively expressed pectate lyase gene pelB from Fusarium solani f. sp. pisi (Nectria haematococca, mating type VI) and characterization of the gene product expressed in Pichia pastoris," Journal of Bacteriology, vol. 177, no. 24, pp. 7070-7077, 1995.

[45] P. K. Yadav, V. K. Singh, S. Yadav, K. D. S. Yadav, and D. Yadav, "In silico analysis of pectin lyase and pectinase sequences," Biochemistry, vol. 74, no. 9, pp. 1049-1055, 2009.

[46] J. D. Thompson, T. J. Gibson, F. Plewniak, F. Jeanmougin, and D. G. Higgins, "The ClustalX windows interface: fexible strategies for multiple sequence alignment aided by quality analysis tools," Nucleic Acids Research, vol. 25, no. 24, pp. 4876-4882, 1997.

[47] K. Tamura, J. Dudley, M. Nei, and S. Kumar, "MEGA4: molecular evolutionary genetics analysis (MEGA) software version 4.0," Molecular Biology and Evolution, vol. 24, no. 8, pp. 1596-1599, 2007.

[48] T. L. Bailey and C. Elkan, "Fitting a mixture model by expectation maximization to discover motifs in biopolymers," in Proceedings of the 2nd International Conference on Intelligent Systems for Molecular Biology, pp. 28-36, AAAI Press, 1994. 

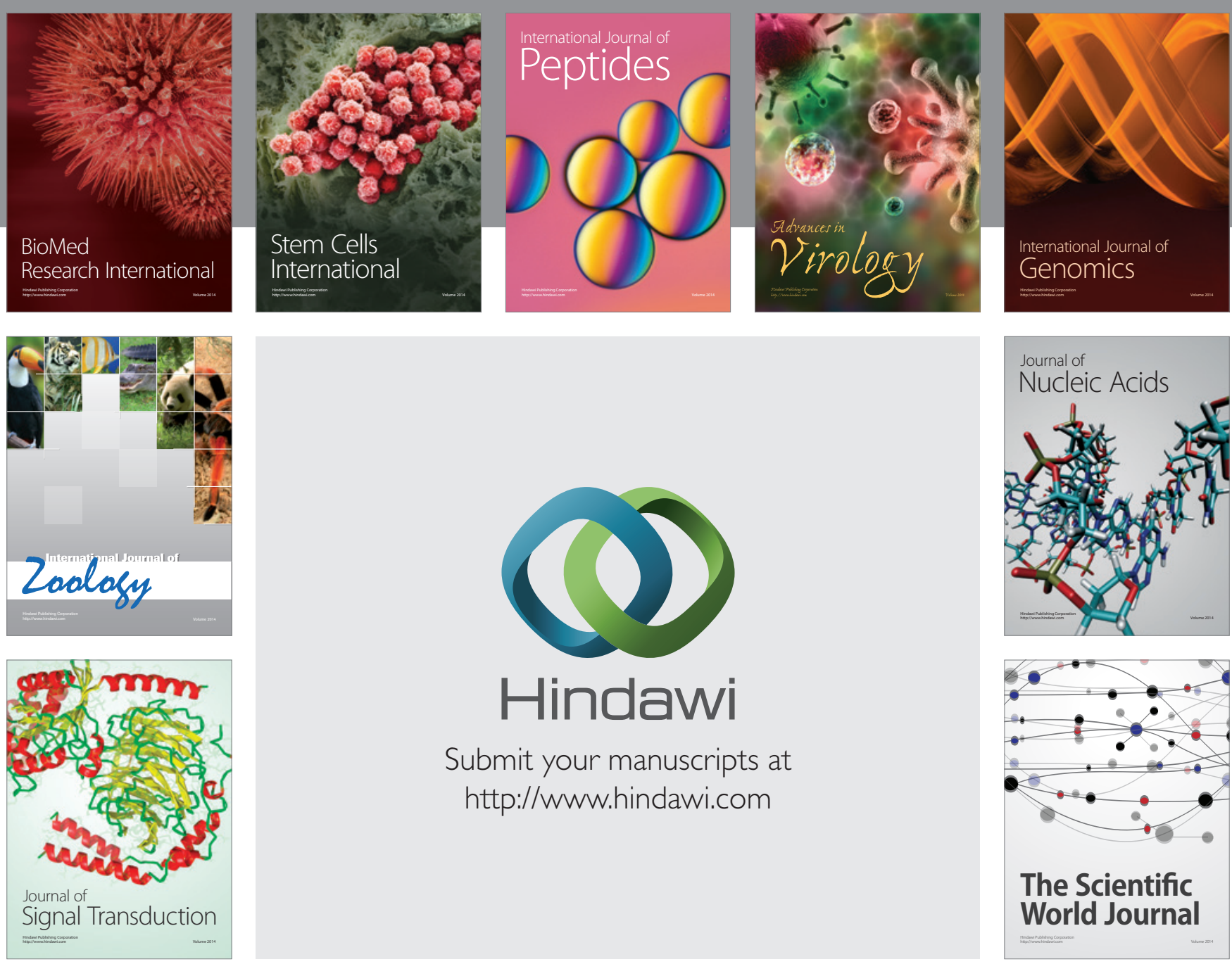

Submit your manuscripts at

http://www.hindawi.com
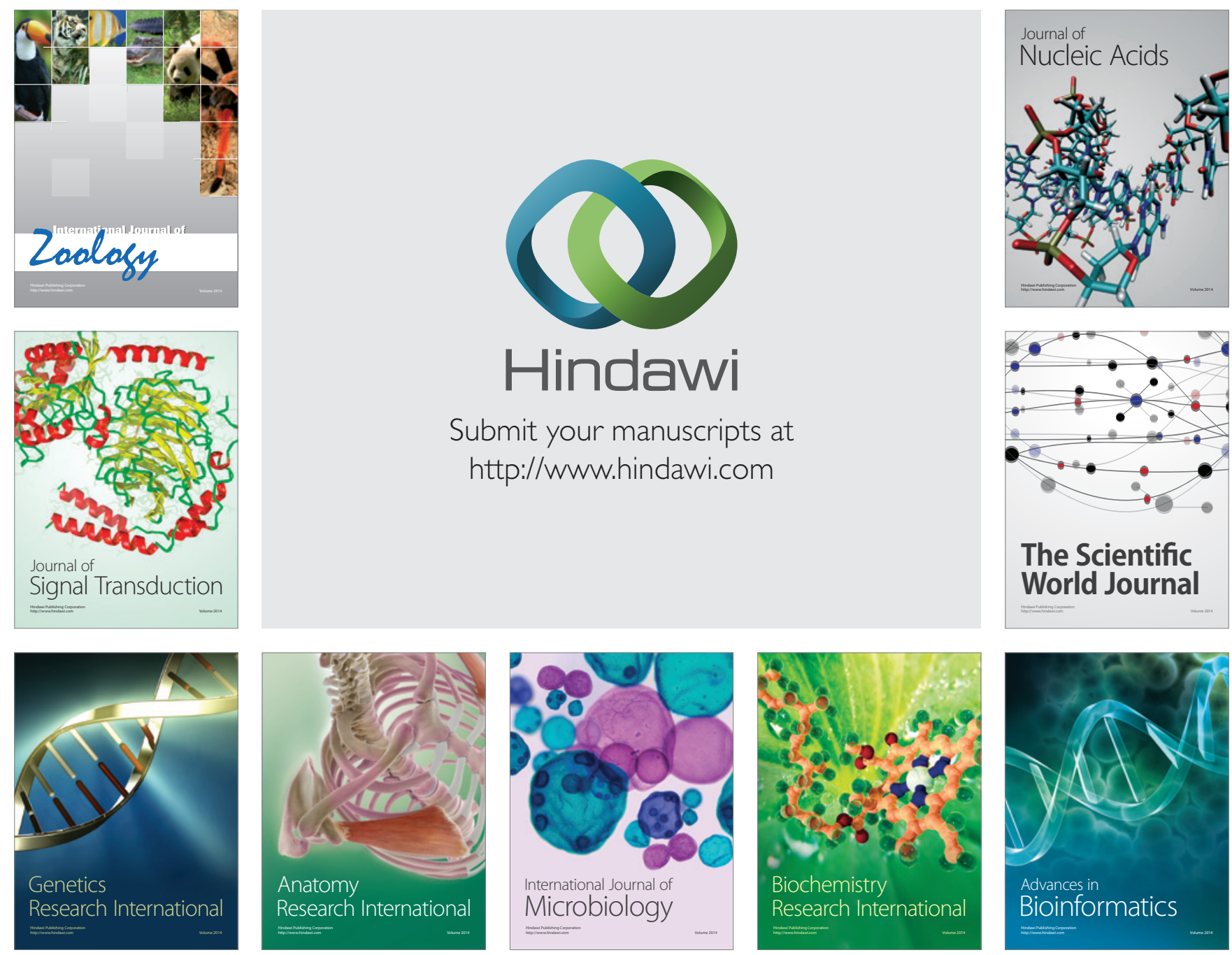

The Scientific World Journal
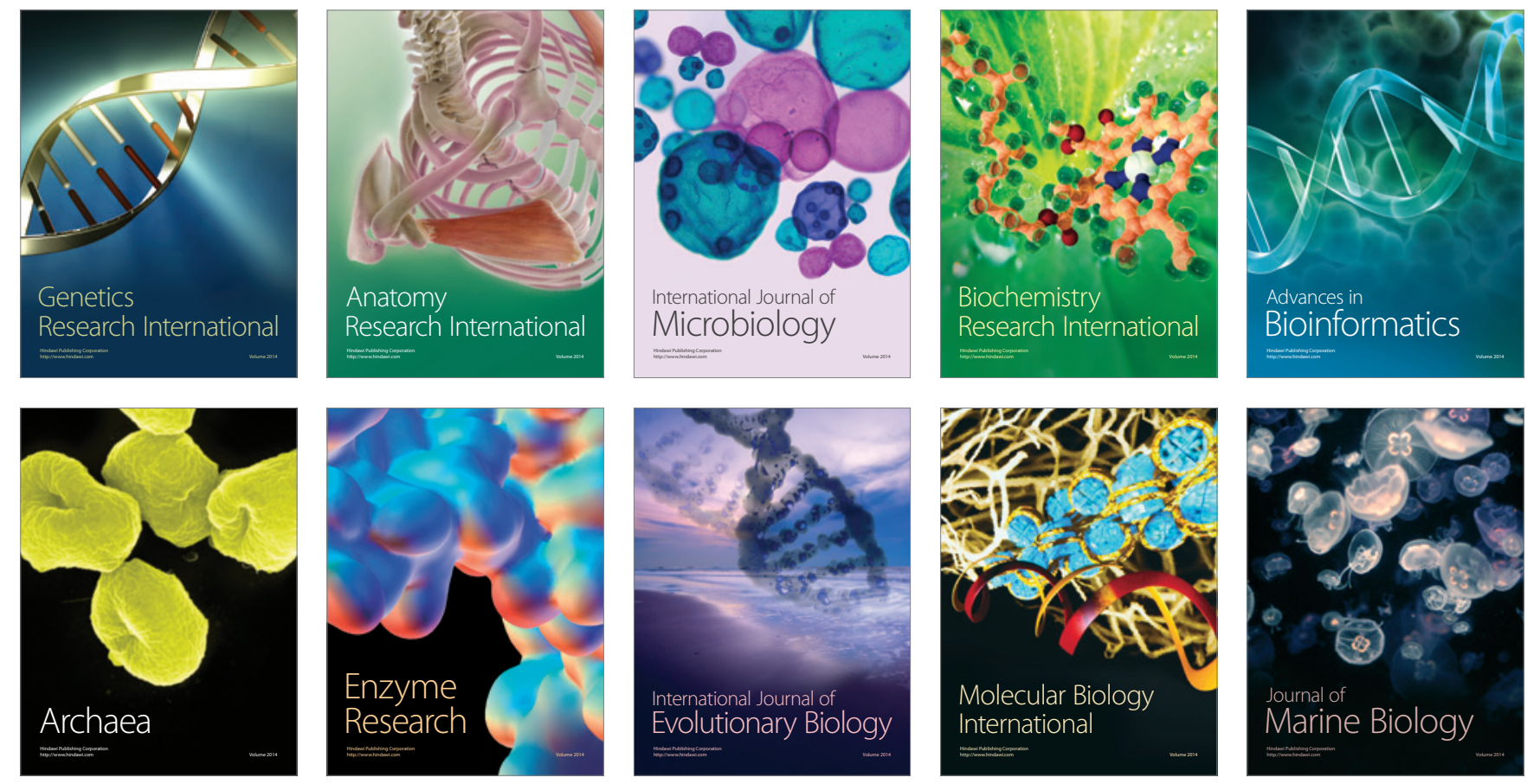